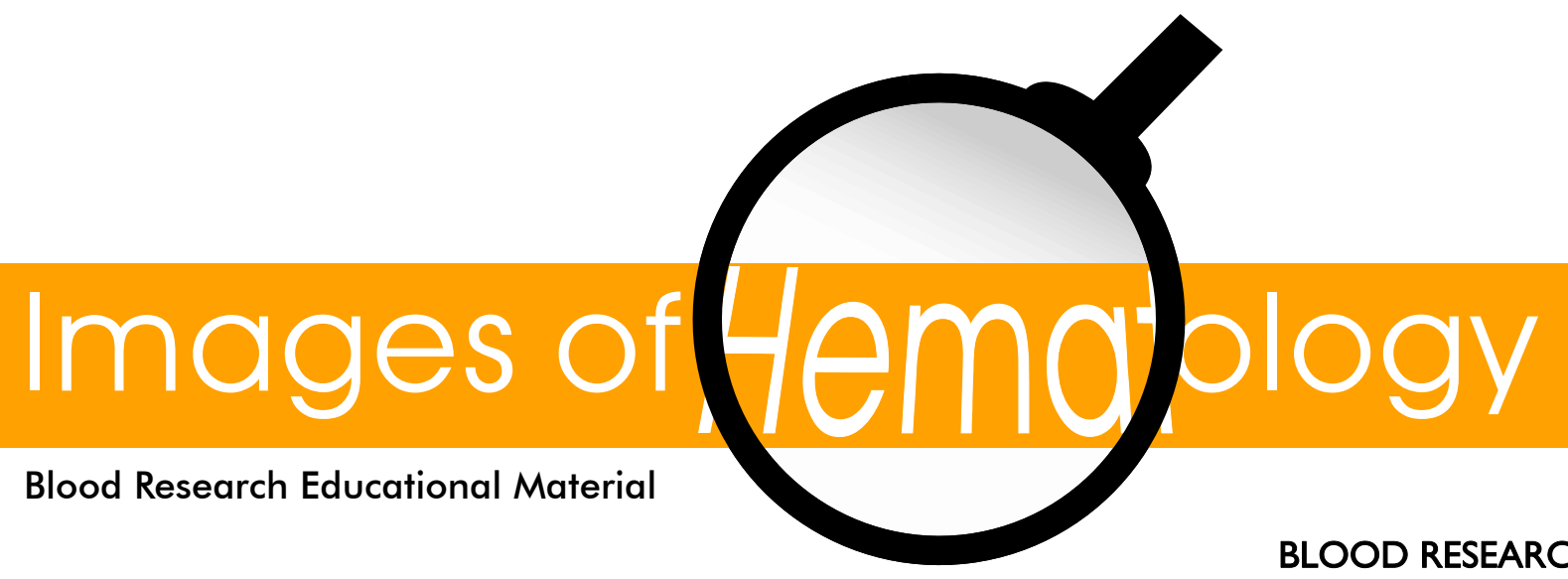

Volume $54 \cdot$ Number $4 \cdot$ December 2019

https://doi.org/10.5045/br.2019.54.4.242

\title{
Recurred breast cancer presenting with autoimmune hemolytic
}

\section{anemia}

Joowon Park

Department of Laboratory Medicine, Dankook University Hospital, Cheonan, Korea

Received on August 22, 2019; Revised on August 26, 2019; Accepted on September 20, 2019

Correspondence to Joowon Park, M.D., Department of Laboratory Medicine, Dankook University College of Medicine, 201 Manghyang-ro, Dongnam-gu, Cheonan 31116, Korea, E-mail: joowon@dankook.ac.kr
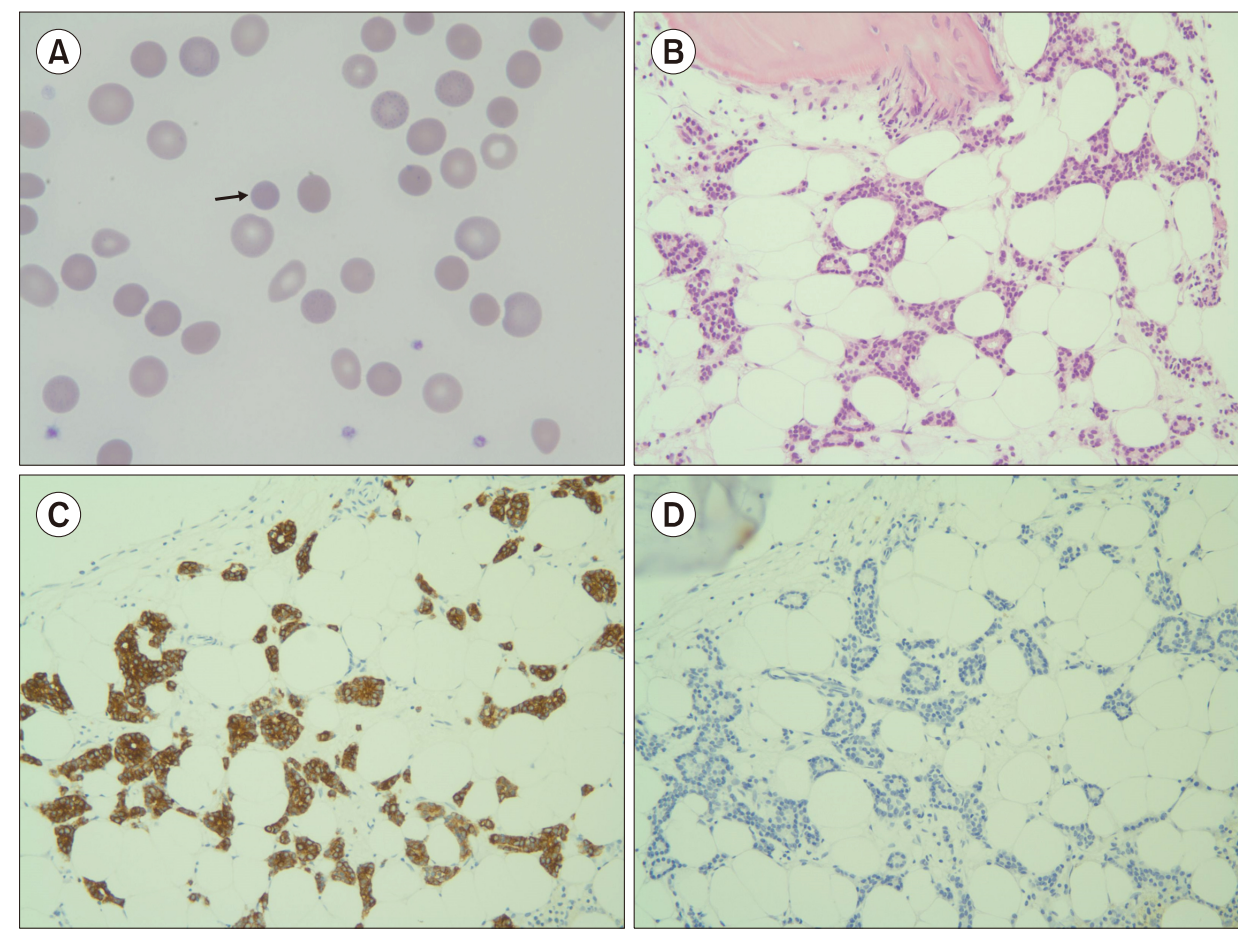

A 61-year-old woman was admitted to our hospital with lower back pain. Seven years ago, she had undergone modified radical mastectomy of the right breast due to invasive ductal carcinoma. Her blood cell counts on admission were as follows: WBC, $5.3 \times 10^{9} / \mathrm{L}$ (neutrophils $54 \%$, lymphocytes 33\%, monocytes $9 \%$, eosinophils $3 \%$, basophils $1 \%$ ); Hb, 7.8 g/dL; platelets, $127 \times 10^{9} / \mathrm{L}$; and absolute reticulocyte count, $262 \times 10^{9} / \mathrm{L}$. A direct Coombs' test was positive for IgG, suggesting warm antibody autoimmune hemolytic anemia (AIHA). Peripheral blood smear showed polychromasia and spherocytosis (A, wright stain, $\times 1,000$, arrow). Bone marrow (BM) biopsy revealed multiple deposits of atypical mononuclear cells (B, H\&E stain, $\times 200)$, which showed positivity for cytokeratin 7 (C, CK7 stain, $\times 200$ ) and negativity for cytokeratin 20 (D, CK20 stain, $\times 200$ ). The carbohydrate antigen 15-3 level was elevated at $118.8 \mathrm{U} / \mathrm{mL}(0-30 \mathrm{U} / \mathrm{mL})$. Recurrence of the underlying cancer was suspected on subsequent positron emission tomography-computed tomography. Based on these findings, a diagnosis of BM metastasis of invasive ductal carcinoma clinically from breast was made. As AIHA is rarely associated with solid tumors, detection of autoantibodies is important for a proper treatment of the underlying disease. It has been suggested that induction of the release of inflammatory mediators, such as interleukins, causes immune-mediated hemolysis in cancer patients.

80 This is an Open Access article distributed under the terms of the Creative Commons Attribution Non-Commercial License (http://creativecommons.org/licenses/by-nc/4.0) 80 which permits unrestricted non-commercial use, distribution, and reproduction in any medium, provided the original work is properly cited. 